\title{
Iron Therapy
}

\section{Ewa A Jankowska ${ }^{1,2}$, Marcin Drozd ${ }^{1,2}$, Michał Tkaczyszyn ${ }^{1,2}$, Piotr Ponikowski ${ }^{1,2}$}

1. Department of Heart Diseases, Wroclaw Medical University, Poland

2. Centre for Heart Diseases, University Hospital, Wroclaw, Poland

\section{Corresponding author:}

Prof. Ewa A. Jankowska, MD PhD, Laboratory for Applied Research on Cardiovascular System, Department of Heart Diseases, Wrocław Medical University, ul. Borowska 213, Wrocław, Poland Email: ewa.jankowska@umed.wroc.pl

\begin{abstract}
Iron deficiency (ID) is one of the most common co-morbidities in patients with heart failure (HF). It has its highest prevalence in elderly subjects, women, decompensated subjects, and patients with numerous co-morbidities. ID is associated with worse symptoms, poorer quality of life, reduced exercise capacity, and a high morbidity and mortality. Both ID and the anaemia it can lead to can be harmful in HF. Repletion of iron stores has been shown to be effective in HF and detection and treatment of ID are now recommended in major HF guidelines. This paper summarises iron therapy for ID in HF patients.
\end{abstract}

Keywords: heart failure; iron; iron deficiency; anaemia; iron supplementation therapy

Citation: Jankowska E, Drozd M, Tkaczyszyn M, Ponikowski P. Iron Therapy. International Cardiovascular Forum Journal. 2019;18:36-40. DOI: 10.17987/icfj.v18i0.625

\section{Introduction}

Iron deficiency (ID) belongs to the most common co-morbidities in patients with heart failure (HF), with the highest prevalence in elderly subjects, women, decompensated subjects, patients with numerous co-morbidities, including those with diabetes and chronic kidney disease (CKD).[1-3] ID has several unfavourable consequences for patients with HF, including augmented HF symptoms, poor quality of life, reduced exercise capacity, high morbidity and mortality.[1-3] ID itself needs to be differentiated from ID-related anaemia (IDA). Although untreated and long-lasting ID can lead to anaemia, ID itself has several clinical negative consequences in HF. Luckily, there are safe and effective therapeutic options, which thorough the repletion of ID (regardless of concomitant anaemia), bring clinical benefits for patients with HF.[4-6]

\section{Pathophysiology of iron deficiency in heart failure} Iron plays a crucial role for optimal functioning of both haematopoietic and non-haematopoietic cells, being directly involved mainly in aerobic cellular energy metabolism in mitochondria.[1,7] Therefore, iron is particularly crucial for optimal functioning of tissues with high energy demand, such as myocardium and skeletal muscles.[1] This is in opposition to traditional approach, which has related ID with the development of anaemia, immunodeficiency and coagulopathy.[1,8]

The underlying mechanisms of the origin of ID in patients with $\mathrm{HF}$ is unknown. Based on our historical understanding of iron metabolism, the development of ID is associated with reduced iron intake, excessive iron loss and/or abnormal iron distribution to body compartments, where it remains unavailable for cells requiring iron for their metabolic needs. Some evidence suggests that ID can be secondary to inadequate dietary iron intake $[9,10]$ or/and reduced gastrointestinal iron bioavailability (due to intestine wall oedema, use of drugs increasing gastric $\mathrm{pH}$, food reducing iron absorption) in patients with HF.[11,12] ID can result from gastrointestinal iron loss, due to local inflammation or concomitant therapy with antiplatelets or/and anticoagulants. It should be noted that none of these potential pathomechanisms have been proven to promote ID in the course of HF.

Although anticipated, the pathogenesis of ID in the course of $\mathrm{HF}$ is different from the pathomechanisms leading to ID in the course of CKD. Patients with CKD develop predominantly functional ID, as a consequence of augmented inflammation and high circulating hepcidin, which traps iron in the mononuclear phagocyte system and makes it unavailable for metabolic needs.[7,13-15] It should be emphasised that - although hypothesised - there is no evidence linking inflammation and ID in patients with HF. Importantly, patients with HF both in chronic [2] and acute settings [3] demonstrate extremely low (but not high) circulating hepcidin, indicating severely depleted iron stores in the body. ID in the course HF is absolute in the vast majority of cases.

\section{Diagnosis of iron deficiency in heart failure}

Based on haematological practices, bone-marrow aspiration with the assessment of iron content directly in bone marrow is the 'gold standard' method to identify ID. [8,16-19] Due to its invasiveness and limited accessibility in a daily clinical practice (particularly among patients with cardiovascular diseases), the 
approach based on the assessment of circulating iron biomarkers is more convenient for the diagnosis of ID in patients with HF. Circulating ferritin is a reliable surrogate of iron stored in the body (mainly in hepatocytes and reticuloendothelial cells). In general, the lower the serum ferritin, the more depleted are the iron stores in the body. But ferritin is also an acute phase protein, hence its production is increased in case of accompanying inflammation. $[8,19,20]$ Therefore, in a general population, absolute ID is diagnosed when serum ferritin is $<30 \mu \mathrm{g} / \mathrm{L}$ or even $<12-15 \mu \mathrm{g} / \mathrm{L}$ $[8,19,21]$ However, due to concomitant low-grade inflammation present in the course of HF, higher cut-off values of serum ferritin are valid for the diagnosis of ID in patients with HF.

The second iron biomarker required for the diagnosis of ID is transferrin saturation (Tsat), which indicates a reduced pool of utilized iron. Tsat is the percentage of transferrin which binds iron, and is calculated as a ratio of serum iron and TIBC $\times 100 \%$ (TIBC, total iron binding capacity - by transferrin).[1] It is worthy of note that neither serum iron nor serum transferrin alone are recommended for the diagnosis of ID in patients with HF.

The 2016 ESC/HFA guidelines on HF management recommend routine screening for ID using serum ferritin and Tsat among all patients with HF, regardless of haemoglobin level, LVEF, renal function, etc.[22] They recommend to use the following definition of ID: serum ferritin $<100 \mu \mathrm{g} / \mathrm{L}$, or ferritin between 100-299 $\mu \mathrm{g} / \mathrm{L}$ and Tsat $<20 \%$.[22] This definition has been used in CKD [20] and also in major clinical trials in HF with intravenous and ora iron supplementation.[4-6,23]

Other novel iron biomarkers are under investigation in HF, but so far without any clinical implications. Our group has recently proposed a new pathophysiological definition of ID using the combination of low serum hepcidin (indicating depleted iron stores more accurately than ferritin, regardless of concomitant inflammation) and high serum soluble transferrin receptor (sTfR) (indicating intracellular iron depletion).[2,3] TfR is the membrane molecular pathway for iron import into the cell; it is upregulated when intracellular metabolic needs for iron are not met, as the augmented membrane expression of TfR facilitates the iron influx to the cells; the overexpressed TfR is later shed to the circulation and is detected as a soluble form.[24]

\section{Prevalence of iron deficiency in heart failure}

ID is a common co-morbidity in patients with HF. When applying the definition of ID recommended by the 2016 ESC/ HFA guidelines on HF management [22], the prevalence of ID in a general population of HF patients ranges between $37-74 \%$. [2,3,25-32] ID is present across the whole spectrum of HF, regardless of LVEF.[27,31-33]

The following clinical features increase the risk for ID among patients with HF: female gender, advanced NYHA class, high plasma N-terminal pro-B-type natriuretic peptide (NT-pro-BNP), high serum high-sensitivity C-reactive protein (hsCRP), low haemoglobin level and decompensated status.[26,27,29,33]

\section{Clinical consequences of iron deficiency in heart failure}

ID translates into impaired aerobic performance expressed as lower peak oxygen consumption VO2 (peak VO2), higher ventilatory response to exercise (VE-VCO2 slope) in patients with HFrEF and HFpEF $[25,30,34]$, and reduced submaximal exercise capacity reflected by the shorter 6-minute walking test (6MWT) distance in patients with HFrEF and HFpEF.[30] It should be noted that the unfavourable impact of ID on both peak VO2 and VE-VCO2 slope in patients with stable HFrEF has been independent and much stronger than the effect of anaemia on these parameters.[34] ID also worsens health related quality of life (HRQoL) expressed, for example using the Minnesota Living with Heart Failure Questionnaire in patients with HF.[35,36]

Among cohorts including patients within the whole spectrum of HF, ID (regardless of accompanying anaemia) has been shown to be an independent predictor of higher all-cause mortality, an increased risk of heart transplantation, and an increased risk of the composite endpoint of mortality and nonfatal cardiovascular events (HF hospitalization, acute coronary syndrome, severe arrhythmia or stroke).[3,25,26,27,29,37,38,39]

\section{Oral iron supplementation in heart failure}

Until now, only one study investigating oral iron supplementation in patients with HF has been executed and published, the IRONOUT-HF study.[23] Patients with symptomatic HFrEF (LVEF $\leq 40 \%$, NYHA class II-IV) and ID defined as previously (serum ferritin 15-100 $\mu \mathrm{g} / \mathrm{L}$, or serum ferritin 101-299 $\mu \mathrm{g} / \mathrm{L}$ with Tsat $<20 \%$; with a haemoglobin level $9-15 \mathrm{~g} / \mathrm{dL}$ for males and 9-13.5 $\mathrm{g} / \mathrm{dL}$ for females) were randomized to either oral iron polysaccharide (150 mg twice daily) $(n=111)$ or placebo $(n=114)$ for 16 weeks. The primary endpoint, a change in peak VO2, did not differ between the oral iron and placebo groups; in addition there were no differences between treatment groups in changes in 6MWT distance. Oral iron supplementation as compared to placebo treatment resulted in clinically meaningless increases in Tsat $(+3 \%, \mathrm{p}=0.003)$ and serum ferritin $(+11 \mu \mathrm{g} / \mathrm{L}, \mathrm{p}=0.06$, borderline).[23] These results do not support the use of oral iron supplementation in patients with HFrEF.

\section{Intravenous iron supplementation in heart failure}

It should be emphasised that earlier parenteral iron preparations were administered as an iron oxyhydroxide complex [40,41] which induced a lot of free and toxic iron, translating into oxidative stress and related adverse events, such as: hypotension, nausea, vomiting, abdominal and lower back pain, peripheral oedema and a metallic taste.[42,43] The contemporary parenteral formulas (mainly ferric carboxymaltose, FCM) contain iron in a core surrounded by a carbohydrate shell, which has allowed to eliminate the aforementioned adverse reactions and side effects.[44]

The majority of clinical evidence regarding intravenous iron supplementation in patients with $\mathrm{HF}$ comes from 3 clinical trials. [4-6] In the FAIR-HF study [4], the Ganzoni formula [45] was used to calculate the required cumulative FCM dose, based on current body weight, actual and the target haemoglobin level of a supplemented patient. The dosing frequency was $200 \mathrm{mg}$ of FCM weekly until iron repletion was achieved (the correction phase) and then every 4 weeks during the maintenance phase. In the CONFIRM-HF study [5] as well as in the EFFECT-HF study [6], FCM was administered according to a fixed scheme based on the subject's weight and haemoglobin concentration at screening and administered at weeks 0 and 6 . Further FCM 
doses could be administered at weeks 12,24 , and 36 if ID was still present, but more than $75 \%$ of patients required only 2 doses in total. This new dosage pattern was in alignment with the total iron dosing applied in the FAIR-HF study.[46]

In the FAIR-HF study, 304 ambulatory patients with symptomatic HF with LVEF $\leq 40 \%$ (NYHA II) or $\leq 45 \%$ (NYHA III), with ID (serum ferritin $<100 \mu \mathrm{g} / \mathrm{L}$, or serum ferritin 100-300 $\mu \mathrm{g} / \mathrm{L}$ and Tsat $<20 \%$ ) with haemoglobin $9.5-13.5 \mathrm{~g} / \mathrm{dL}$ were randomized in a $2: 1$ ratio to either intravenous FCM (dosing already explained above) or intravenous saline. Primary endpoints were self-reported patient global assessment (PGA) at week 24 and NYHA class at week 24, adjusted for baseline NYHA class, both of which improved in the FCM arm as compared to a saline control.[4] The improvement in aforementioned characteristics were seen separately in both anaemic and non-anaemic patients, even though the clinical improvement in non-anaemic patients was not accompanied by an increase in haemoglobin level.[46] The treatment with FCM (as compared with placebo administration) resulted also in an increase of the 6MWT distance and quality of life assessments. The rates of death, adverse events, and serious adverse events were similar in the two study groups.[4]

In the CONFIRM-HF study, ambulatory patients with HF in NYHA class II-III with LVEF $\leq 45 \%$, BNP $>100 \mathrm{pg} / \mathrm{mL}$ or NT-proBNP $>400 \mathrm{pg} / \mathrm{mL}$, with ID (defined as in the FAIR-HF study) and haemoglobin level $<15 \mathrm{~g} / \mathrm{dL}$ were randomized 1:1 to either FCM or placebo for 52 weeks (doses as described above). Treatment with FCM as compared to placebo increased the 6MWT distance at week 24 (primary endpoint).[5] The treatment effect of FCM was consistent in all clinical subgroups and was seen up to week 52. Throughout the study, an improvement in NYHA class, PGA, QoL, and Fatigue Score in patients treated with FCM was demonstrated with a statistical significance confirmed from week 24 onwards. Treatment with FCM as compared to placebo was associated with a reduction in the risk of HF hospitalizations at week 52 (one of the secondary endpoints). The number of deaths and adverse events were similar in both study groups.[5]

In the EFFECT-HF study, ambulatory patients with HF in NYHA class II-III with LVEF $\leq 45 \%$, a reproducible peak VO2 of 10 to 20 $\mathrm{mL} / \mathrm{kg} / \mathrm{min}, \mathrm{BNP}>100 \mathrm{pg} / \mathrm{mL}$ or NT-proBNP $>400 \mathrm{pg} / \mathrm{mL}$, with ID (defined as in the FAIR-HF study) and haemoglobin level $<15$ $\mathrm{g} / \mathrm{dL}$ were randomized $1: 1$ to either FCM or standard care for 24 weeks (doses as in the CONFIRM-HF study).[6] At 24 weeks, peak VO2 (primary endpoint) decreased in the control group, but was maintained on FCM $(p<0.05)$. PGA and NYHA class also improved on FCM as compared to standard of care.[6]

In other smaller studies in patients with HFrEF, the following beneficial effects of intravenous iron therapy were demonstrated: within echocardiography parameters (an increase in LVEF, a reduction in LVSD, LVDD, LVPW, IVS thickness, left ventricular mass index, left ventricular end systolic volume, an improvement in S', E', a decline in E/E', a reduction in peak systolic strain rate) [47-51] and within some biomarkers (a reduction in plasma NTproBNP and CRP.[48]

Recently 2 meta-analyses (one based on a classical methodological approach [52], the other one using individual patient data [53]) have provided additional evidence regarding the safety and efficacy of intravenous iron supplementation in patients with HF.

The meta-analysis of Jankowska EA et al. included 5 trials in iron deficient patients with HF and LVEF $\leq 45 \%$ (509 patients received intravenous iron therapy - the majority were treated with FCM - compared with 342 controls), with at least a single-blind randomization without a concomitant therapy with erythropoiesisstimulating agents.[52] This meta-analysis revealed that intravenous iron therapy in iron deficient patients with HF and LVEF $\leq 45 \%$ reduced the risk of the combined endpoint of all-cause death or cardiovascular hospitalization, the risk of the combined endpoint of cardiovascular death or HF hospitalization, and the risk of HF hospitalization, but without an effect on either all-cause or cardiovascular mortality (which may be due to a low number of reported events and a relatively short follow-up).[52]

The meta-analysis of Anker SD et al. utilized the individual patient data extracted from four clinical trials comparing FCM $(n=504)$ with placebo $(n=335)$ in iron deficient patients with systolic HF.[53] As compared with a placebo group, patients receiving FCM had lower rates of recurrent CV hospitalizations and CV mortality, lower rates of recurrent HF hospitalizations and CV mortality, lower rates of recurrent CV hospitalizations and allcause mortality.[53] Time-to-first-event analyses showed similar findings, with a somewhat attenuated treatment effects.[53]

\section{Clinical implications}

All aforementioned evidence led to the formulation of the following recommendations regarding the diagnosis and treatment of ID in patients with HF in 2016 ESC/HFA guidelines on HF management [22]:

"The following diagnostic tests (including ferritin and transferrin saturation) are recommended for initial assessment of a patient with newly diagnosed HF in order to evaluate the patient's suitability for particular therapies, to detect reversible/treatable causes of HF and comorbidities interfering with HF (Class of recommendations I, Level of evidence C)."

"Intravenous FCM should be considered in symptomatic patients with HFrEF and iron deficiency (serum ferritin $<100$ $\mu \mathrm{g} / \mathrm{L}$, or ferritin between 100-299 $\mu \mathrm{g} / \mathrm{L}$ and transferrin saturation $<20 \%$ ) in order to alleviate HF symptoms and improve exercise capacity and quality of life (Class of recommendations Ila, Level of evidence A)".

\section{Future directions}

ID is highly prevalent and has numerous unfavourable consequences for patients with HF across the whole spectrum of LVEF, but surprisingly its origin still remains unknown. Although intravenous iron supplementation has been shown to improve exercise capacity, improve quality of life and alleviate HF symptoms in iron deficient patients with HFrEF, there is no definitive data that this therapy would also improve clinical outcomes in this patient population. Also, it has not been demonstrated if intravenous iron supplementation is safe and effective in iron deficient patients with acute HF and patients with $\mathrm{HFmrEF/HFpEF}$. Therefore, a series of trials is ongoing in order to validate the aforementioned concepts (HEART-FID, AFFIRMAHF, FAIR-HF2, FAIR-HFPEF, PREFER-HF, IRONMAN). 


\section{Declarations of interest}

The authors declare no conflict of interest.

\section{Acknowledgement}

The preparation of the manuscript was supported by the National Science Centre (Poland) grant number 2014/13/B/NZ5/03146.

\section{References}

1. Jankowska EA, Von Haehling S, Anker SD, MacDougall IC, Ponikowski P. Iron deficiency and heart failure: Diagnostic dilemmas and therapeutic perspectives. Eur Heart J 2013;34:816-826.

2. Jankowska EA, Malyszko J, Ardehali H, Koc-Zorawska E, Banasiak W, von Haehling S, Macdougall IC, Weiss G, McMurray JJ V, Anker SD, Gheorghiade M, Ponikowski P. Iron status in patients with chronic heart failure. Eur Heart J 2013;34:827-834.

3. Jankowska EA, Kasztura M, Sokolski M, Bronisz M, Nawrocka S, Ole kowska-Florek W, Zymli ski R, Biegus J, Siwo owski P, Banasiak W, Anker SD, Filippatos G, Cleland JGF, Ponikowski P. Iron deficiency defined as depleted iron stores accompanied by unmet cellular iron requirements identifies patients at the highest risk of death after an episode of acute heart failure. Eur Heart J 2014;35:2468-2476.

4. Anker SD, Comin Colet J, Filippatos G, Willenheimer R, Dickstein K, Drexler H, Lüscher TF, Bart B, Banasiak W, Niegowska J, Kirwan B, Mori C, von Eisenhart Rothe B, Pocock SJ, Poole-Wilson PA, Ponikowski P. Ferric Carboxymaltose in Patients with Heart Failure and Iron Deficiency. N Engl J Med 2009;361:2436-2448.

5. Ponikowski P, van Veldhuisen DJ, Comin-Colet J, Ertl G, Komajda M, Mareev V, McDonagh T, Parkhomenko A, Tavazzi L, Levesque V, Mori C, Roubert B, Filippatos G, Ruschitzka F, Anker SD. Beneficial effects of longterm intravenous iron therapy with ferric carboxymaltose in patients with symptomatic heart failure and iron deficiency. Eur Heart J 2015;36:657-668.

6. van Veldhuisen DJ, Ponikowski P, van der Meer P, Metra M, Böhm M, Doletsky A, Voors AA, Macdougall IC, Anker SD, Roubert B, Zakin L, Cohen-Solal A; EFFECT-HF Investigators. Effect of Ferric Carboxymaltose on Exercise Capacity in Patients With Chronic Heart Failure and Iron Deficiency. Circulation. 2017;136:1374-1383.

7. Andrews NC. Disorders of iron metabolism. N Engl J Med 1999;341:19861995.

8. Goodnough LT, Nemeth E, Ganz T. Detection, evaluation, and management of iron-restricted erythropoiesis. Blood 2010;116:4754-4761.

9. Hughes CM, Woodside J V, McGartland C, Roberts MJ, Nicholls DP, McKeown PP. Nutritional intake and oxidative stress in chronic heart failure. Nutr Metab Cardiovasc Dis Elsevier; 2012;22:376-382.

10. Lourenço $\mathrm{BH}$, Vieira LP, Macedo A, Nakasato M, Marucci M de FN, Bocchi EA. Nutritional status and adequacy of energy and nutrient intakes among heart failure patients. Arq Bras Cardiol 2009;93:541-548.

11. Hallberg L, Hulthén L. Prediction of dietary iron absorption: An algorithm for calculating absorption and bioavailability of dietary iron. Am J Clin Nutr 2000;71:1147-1160.

12. González-Costello J, Comín-Colet J. Iron deficiency and anaemia in heart failure: Understanding the FAIR-HF trial [Internet]. Eur. J. Heart Fail. 2010. p. 1159-1162.

13. Nemeth E, Ganz T. Regulation of iron metabolism by hepcidin. Annu Rev Nutr 2006;26:323-342.

14. Nicolas G, Bennoun M, Porteu A, Mativet S, Beaumont C, Grandchamp B, Sirito M, Sawadogo M, Kahn A, Vaulont S. Severe iron deficiency anemia in transgenic mice expressing liver hepcidin. Proc Natl Acad Sci U S A 2002:99:4596-4601.

15. Silvestri L. Inhibiting the hepcidin inhibitor for treatment of iron overload. Blood. 2013. p. 1068-1069.

16. Moreno Chulilla JA, Romero Colás MS, Gutiérrez Martín M. Classification of anemia for gastroenterologists. World J Gastroenterol 2009;15:4627-4637.

17. Goddard AF, James MW, McIntyre AS, Scott BB, British Society of Gastroenterology. Guidelines for the management of iron deficiency anaemia. Gut 2011;60:1309-1316.

18. Gale E, Torrance J, Bothwell T. The quantitative estimation of total iron stores in human bone marrow. J Clin Invest American Society for Clinical Investigation; 1963;42:1076-1082.19.

19. Pasricha S-RS, Flecknoe-Brown SC, Allen KJ, Gibson PR, McMahon LP, Olynyk JK, Roger SD, Savoia HF, Tampi R, Thomson AR, Wood EM, Robinson $\mathrm{KL}$. Diagnosis and management of iron deficiency anaemia: a clinical update. Med J Aust 2010;193:525-532.

20. Wish JB. Assessing Iron Status: Beyond Serum Ferritin and Transferrin Saturation. Clin J Am Soc Nephrol American Society of Nephrology; 2006;1:S4-S8

21. Ali MA, Luxton AW, Walker WH. Serum ferritin concentration and bone marrow iron stores: a prospective study. Can Med Assoc J Canadian Medical Association; 1978;118:945-946.

22. Ponikowski P, Voors AA, Anker SD, Bueno H, Cleland JG, Coats AJ, Falk V, González-Juanatey JR, Harjola VP, Jankowska EA, Jessup M, Linde C, Nihoyannopoulos P, Parissis JT, Pieske B, Riley JP, Rosano GM,
Ruilope LM, Ruschitzka F, Rutten FH, van der Meer P; Authors/Task Force Members; Document Reviewers. 2016 ESC Guidelines for the diagnosis and treatment of acute and chronic heart failure: The Task Force for the diagnosis and treatment of acute and chronic heart failure of the European Society of Cardiology (ESC). Eur J Heart Fail. 2016;18:891-975.

23. Lewis GD, Malhotra R, Hernandez AF, McNulty SE, Smith A, Felker GM, Tang WHW, LaRue SJ, Redfield MM, Semigran MJ, Givertz MM, Van Buren P, Whellan D, Anstrom KJ, Shah MR, Desvigne-Nickens P, Butler J, Braunwald E; NHLBI Heart Failure Clinical Research Network. Effect of Oral Iron Repletion on Exercise Capacity in Patients With Heart Failure With Reduced Ejection Fraction and Iron Deficiency: The IRONOUT HF Randomized Clinical Trial. JAMA. 2017;317:1958-1966.

24. Koulaouzidis A, Said E, Cottier R, Saeed AA. Soluble transferrin receptors and iron deficiency, a step beyond ferritin. A systematic review. J Gastrointestin Liver Dis 2009;18:345-352.

25. Okonko DO, Mandal AKJ, Missouris CG, Poole-Wilson PA. Disordered iron homeostasis in chronic heart failure: Prevalence, predictors, and relation to anemia, exercise capacity, and survival. J Am Coll Cardiol Elsevier Inc.; 2011;58:1241-1251.

26. Jankowska EA, Rozentryt P, Witkowska A, Nowak J, Hartmann O, Ponikowska B, Borodulin-Nadzieja L, Banasiak W, Polonski L, Filippatos G, McMurray JJ V, Anker SD, Ponikowski P. Iron deficiency: An ominous sign in patients with systolic chronic heart failure. Eur Heart J 2010;31:18721880.

27. Klip IT, Comin-Colet J, Voors AA, Ponikowski P, Enjuanes C, Banasiak W, Lok DJ, Rosentryt P, Torrens A, Polonski L, Van Veldhuisen DJ, Van Der Meer $P$, Jankowska EA. Iron deficiency in chronic heart failure: An international pooled analysis. Am Heart J Mosby, Inc.; 2013;165:575-582.e3.29.

28. Kasner M, Aleksandrov AS, Westermann D, Lassner D, Gross M, Von Haehling S, Anker SD, Schultheiss HP, Tschöpe C. Functional iron deficiency and diastolic function in heart failure with preserved ejection fraction. Int J Cardiol Elsevier Ireland Ltd; 2013;168:4652-4657.

29. Yeo TJ, Yeo PSD, Ching-Chiew Wong R, Ong HY, Leong KTG, Jaufeerally F, Sim D, Santhanakrishnan R, Lim SL, M.Y. Chan M, Chai P, Low AF, Ling LH, Ng TP, Richards AM, Lam CSP. Iron deficiency in a multi-ethnic Asian population with and without heart failure: prevalence, clinical correlates, functional significance and prognosis. Eur J Heart Fail 2014;16:1125-1132.

30. Ebner N, Jankowska EA, Ponikowski P, Lainscak M, Elsner S, Sliziuk V, Steinbeck L, Kube J, Bekfani T, Scherbakov N, Valentova M, Sandek A Doehner W, Springer J, Anker SD, Von Haehling S. The impact of iron deficiency and anaemia on exercise capacity and outcomes in patients with chronic heart failure. Results from the Studies Investigating Co-morbidities Aggravating Heart Failure. Int J Cardiol Elsevier Ireland Ltd; 2016;205:6-12.

31. Núñez J, Domínguez E, Ramón JM, Núñez E, Sanchis J, Santas E, Heredia R, González J, Miñana G, López L, Chorro FJ, Palau P. Iron deficiency and functional capacity in patients with advanced heart failure with preserved ejection fraction. Int J Cardiol Elsevier Ireland Ltd; 2016;207:365-367.

32. Martens P, Nijst P, Verbrugge FH, Smeets K, Dupont M, Mullens W. Impact of iron deficiency on exercise capacity and outcome in heart failure with reduced, mid-range and preserved ejection fraction. Acta Cardiol. 2018;73: 115-123.

33. Cohen-Solal A, Damy T, Terbah M, Kerebel S, Baguet JP, Hanon O, Zannad F, Laperche T, Leclercq C, Concas V, Duvilli L, Darn B, Anker S, Mebazaa A. High prevalence of iron deficiency in patients with acute decompensated heart failure. Eur J Heart Fail 2014;16:984-991.

34. Jankowska EA, Rozentryt P, Witkowska A, Nowak J, Hartmann O, Ponikowska B, Borodulin-Nadzieja L, Von Haehling S, Doehner W, Banasiak W, Polonski L, Filippatos G, Anker SD, Ponikowski P. Iron deficiency predicts impaired exercise capacity in patients with systolic chronic heart failure. J Card Fail Elsevier Inc; 2011;17:899-906.

35. Comín-Colet J, Enjuanes C, González G, Torrens A, Cladellas M, Meroño O, Ribas N, Ruiz S, Gómez M, Verdú JM, Bruguera J. Iron deficiency is a key determinant of health-related quality of life in patients with chronic heart failure regardless of anaemia status. Eur J Heart Fail 2013;15:1164-1172.

36. Enjuanes C, Klip IT, Bruguera J, Cladellas M, Ponikowski P, Banasiak W, van Veldhuisen DJ, van der Meer P, Jankowska EA, Comín-Colet J. Iron deficiency and health-related quality of life in chronic heart failure: Results from a multicenter European study. Int $\mathrm{J}$ Cardiol Elsevier Ireland Ltd; 2014;174:268-275.

37. Parikh A, Natarajan S, Lipsitz SR, Katz SD. Iron deficiency in communitydwelling US adults with self-reported heart failure in the National Health and Nutrition Examination Survey III: Prevalence and associations with anemia and inflammation. Circ Hear Fail 2011;4:599-606.

38. Rangel I, Gonçalves A, de Sousa C, Leite S, Campelo M, Martins E, Amorim S, Moura B, Silva Cardoso J, Maciel MJ. Iron Deficiency Status Irrespective of Anemia: A Predictor of Unfavorable Outcome in Chronic Heart Failure Patients. Cardiology 2014;128:320-326.

39. Aung N, Ling HZ, Cheng AS, Aggarwal S, Flint J, Mendonca M, Rashid M, Kang S, Weissert S, Coats CJ, Richards T, Thomas M, Woldman S, Okonko DO. Expansion of the red cell distribution width and evolving iron deficiency 
as predictors of poor outcome in chronic heart failure. Int $\mathrm{J}$ Cardiol Elsevier; 2013;168:1997-2002.

40. Heath CW, Strauss MB, Castle WB. Quantitative aspects of rion deficiency in hypochromic anemia: (The Parenteral Administration of Iron). J Clin Invest 1932;11:1293-1312.

41. Goetsch AT, Moore CV, Minnich V. Observations on the effect of massive doses of iron given intravenously to patients with hypochromic anemia. J Lab Clin Med 1946;31:466.

42. Silvestri L. Inhibiting the hepcidin inhibitor for treatment of iron overload [Internet]. Blood. 2013. p. 1068-1069.

43. Evans RW, Rafique R, Zarea A, Rapisarda C, Cammack R, Evans PJ, Porter JB, Hider RC. Nature of non-transferrin-bound iron: studies on iron citrate complexes and thalassemic sera. JBIC J Biol Inorg Chem Springer-Verlag; 2007;13:57-74.

44. Macdougall IC. Evolution of iv iron compounds over the last century. J Ren Care 2009;35 Suppl 2:8-13.

45. Ganzoni AM. [Intravenous iron-dextran: therapeutic and experimental possibilities]. Schweiz Med Wochenschr 1970;100:301-303.

46. Filippatos G, Farmakis D, Colet JC, Dickstein K, Lüscher TF, Willenheimer R, Parissis J, Gaudesius G, Mori C, Rothe BVE, Greenlaw N, Ford I, Ponikowski $\mathrm{P}$, Anker SD. Intravenous ferric carboxymaltose in iron-Deficient chronic heart failure patients with and without anaemia: A subanalysis of the FAIR-HF trial. Eur J Heart Fail 2013;15:1267-1276.

47. Bolger AP, Bartlett FR, Penston HS, O'Leary J, Pollock N, Kaprielian R, Chapman CM. Intravenous iron alone for the treatment of anemia in patients with chronic heart failure. J Am Coll Cardiol 2006;48:1225-1227.

48. Toblli JE, Lombraña A, Duarte P, Di Gennaro F. Intravenous Iron Reduces NT-Pro-Brain Natriuretic Peptide in Anemic Patients With Chronic Heart Failure and Renal Insufficiency. J Am Coll Cardiol 2007;50:1657-1665.

49. Okonko DO, Grzeslo A, Witkowski T, Mandal AKJ, Slater RM, Roughton M, Foldes G, Thum T, Majda J, Banasiak W, Missouris CG, Poole-Wilson $\mathrm{PA}$, Anker SD, Ponikowski P. Effect of intravenous iron sucrose on exercise tolerance in anemic and nonanemic patients with symptomatic chronic heart failure and iron deficiency. J Am Coll Cardiol 2008;51:103-112.

50. Usmanov RI, Zueva EB, Silverberg DS, Shaked M. Intravenous iron without erythropoietin for the treatment of iron deficiency anemia in patients with moderate to severe congestive heart failure and chronic kidney insufficiency. J Nephrol 2008;21:236-242.

51. Gaber R, Kotb NA, Ghazy M, Nagy HM, Salama M, Elhendy A. Tissue Doppler and Strain Rate Imaging Detect Improvement of Myocardial Function in Iron Deficient Patients with Congestive Heart Failure after Iron Replacement Therapy. Echocardiography 2012;29:13-18.

52. Jankowska EA, Tkaczyszyn M, Suchocki T, Drozd M, von Haehling S, Doehner W, Banasiak W, Filippatos G, Anker SD, Ponikowski P. Effects of intravenous iron therapy in iron-deficient patients with systolic heart failure: a meta-analysis of randomized controlled trials. Eur $\mathrm{J}$ Heart Fail 2016;18:786-95.

53. Anker SD, Kirwan BA, van Veldhuisen DJ, Filippatos G, Comin-Colet J, Ruschitzka F, Lüscher TF, Arutyunov GP, Motro M, Mori C, Roubert B, Pocock SJ, Ponikowski P. Effects of ferric carboxymaltose on hospitalisations and mortality rates in iron-deficient heart failure patients: an individual patient data meta-analysis. Eur J Heart Fail. 2018;20: 125-133 